\title{
THE EFFECT OF HEMORRHAGE UPON ALDOSTERONE SECRETION IN NORMAL AND HYPOPHYSECTOMIZED DOGS*
}

\author{
By PATRICK J. MULROW AND WILLIAM F. GANONG WITH THE TECHNICAL ASSISTANCE \\ oF ALBERT KULJIAN AND ANGELA BORYCZKA \\ (From the Medical Service, VA Hospital, West Haven, and Department of Medicine, Yale \\ University School of Medicine New Haven, Conn.; and Department of Physiology, \\ University of California School of Medicine, San Francisco, Calif.)
}

(Submitted for publication September 27, 1960; accepted November 21, 1960)

Acute hemorrhage has been demonstrated to stimulate aldosterone output in $\operatorname{dog}$ and man (1-3). Because of the relatively greater increment in aldosterone than in glucocorticoid secretion or excretion, a specific aldosterone-stimulating effect has been postulated. All of these studies, however, were performed in subjects with intact pituitaries. In view of the accumulating evidence (4-8) of the role of ACTH in regulating secretion of aldosterone, especially in the acute experiment, the role of the pituitary in the increment in aldosterone secretion following hemorrhage remains uncertain. The present experiments were designed to compare the effect of acute hemorrhage on aldosterone secretion in normal and in hypophysectomized dogs.

\section{METHODS}

Fifteen male mongrel dogs (9.5 to $15 \mathrm{~kg}$ ) were studied. The normal group of 5 dogs had the right lumboadrenal vein cannulated by the technique of Hume and Nelson (9) on the day prior to the experiment. At the start of the experiment each dog was anesthetized with Nembutal and the right femoral vein and artery were cannulated, the latter for continuous blood pressure recording, using a Grass model 5 polygraph and a Statham strain gage. Ten- to $15-\mathrm{ml}$ samples of adrenal vein blood were collected. Each sample was immediately replaced by dog bank blood to avoid the effects of intermittent small hemorrhages. After two to three control samples, collected at 20 to 30 minute intervals, $15 \mathrm{ml}$ of blood per $\mathrm{kg}$ body weight was withdrawn from the femoral artery within 6 minutes. Collection of the first post-hemorrhage sample of adrenal vein blood was begun 10 minutes after the start of hemorrhage. An additional one or two samples were collected at 20 - to 30 -

* This work has been supported by Grants C-3998 and A-3818 from the United States Public Health Service and a grant-in-aid from The Commonwealth Fund. This report was presented at the meeting of the Federated American Societies for Experimental Biology, Chicago, April, 1960. minute intervals. The shed blood was then transfused over 6 minutes and two to three post-transfusion samples were collected at intervals similar to those of the posthemorrhage period. Following this last sample, 1 IU of ACTH (Upjohn) was administered through the femoral vein and collection of adrenal vein blood was begun 10 minutes later.

Ten dogs were hypophysectomized by the transbuccal route (10), and the right adrenal vein was cannulated on the experimental day. One hour after hypophysectomy, collection of adrenal vein samples was begun. The protocol thereafter was similar to that of the normal dogs. Blood samples were centrifuged immediately after collection, and the plasma was separated and frozen for subsequent analysis. Aldosterone and corticosterone were measured by the isotope derivative technique of Kliman and Peterson (11), and 17-dihydroxycorticoids by the Silber-Porter method (12). Secretion rates were calculated from the concentrations and the plasma flow per minute. Completeness of hypophysectomy was checked by gross examination of the hypothalamus and sella turcica.

\section{RESULTS}

Normal dogs. In Table I are represented the results from five normal dogs. In all five dogs following the acute hemorrhage there was an immediate increment in aldosterone secretion which persisted throughout the post-hemorrhage period. Following transfusion of the shed blood there was a decrement in aldosterone secretion to below post-hemorrhage levels in the first sample in four of the dogs. In all dogs, administration of ACTH resulted in an increment in aldosterone secretion which was greater than the preceding secretory rate, and in four dogs was even greater than the highest post-hemorrhage rate.

The changes in corticosterone and 17-hydroxycorticoid secretion showed two separate patterns. Three dogs (208, 214 and 215) with low control secretion rates showed significant rise in both corticosterone and 17-hydroxycorticoid secretions following hemorrhage, indicating an ACTH-effect. 
TABLE I

Effect of acute hemorrhage upon adrenocortical secretions in normal dogs

\begin{tabular}{|c|c|c|c|c|c|c|c|c|c|c|}
\hline \multirow[b]{2}{*}{ Dog no. } & \multicolumn{3}{|c|}{ Control period } & \multicolumn{3}{|c|}{ Post-hemorrhage period } & \multicolumn{3}{|c|}{ Post-transfusion period } & \multirow{2}{*}{$\begin{array}{c}\text { Post-ACTH } \\
\text { period } \\
10\end{array}$} \\
\hline & 1 & 2 & 3 & 4 & 5 & 6 & 7 & 8 & 9 & \\
\hline \multicolumn{11}{|l|}{201} \\
\hline $\begin{array}{l}\text { Aldosterone* } \\
\text { Corticosterone } \dagger \\
\text { 17-OH corticoids } \dagger \\
\text { Blood pressure } \ddagger \\
\text { Plasma flow§ }\end{array}$ & $\begin{array}{c}56 \\
1.1 \\
11.8 \\
115 / 60 \\
1.1\end{array}$ & $\begin{array}{r}14.7 \\
1.6\end{array}$ & $\begin{array}{c}16 \\
1.4 \\
12.6 \\
120 / 60 \\
1.5\end{array}$ & $\begin{array}{l}54 \\
1.2 \\
11.4 \\
80 / 45 \\
0.9\end{array}$ & $\begin{array}{r}10.6 \\
1.0\end{array}$ & $\begin{array}{c}36 \\
1.0 \\
9.9 \\
105 / 50 \\
1.0\end{array}$ & $\begin{array}{c}25 \\
1.1 \\
9.7 \\
125 / 80 \\
1.4\end{array}$ & $\begin{array}{l}0.7 \\
1.7\end{array}$ & $\begin{array}{c}3 \| \\
0.07 \\
1.3 \\
125 / 75 \\
1.7\end{array}$ & $\begin{array}{c}81 \\
1.6 \\
14.1 \\
125 / 75 \\
1.7\end{array}$ \\
\hline \multicolumn{11}{|l|}{208} \\
\hline $\begin{array}{l}\text { Aldosterone* } \\
\text { Corticosterone } \dagger \\
\text { 17-OH corticoids } \dagger \\
\text { Blood pressureł } \\
\text { Plasma flow§ }\end{array}$ & $\begin{array}{c}14 \\
0.14 \\
7.0 \\
125 / 75 \\
1.2\end{array}$ & $\begin{array}{l}0.4 \\
0.8\end{array}$ & $\begin{array}{c}9 \\
0.18 \\
1.2 \\
135 / 90 \\
1.2\end{array}$ & $\begin{array}{l}47 \\
1.8 \\
10.8 \\
60 / 35 \\
0.4\end{array}$ & $\begin{array}{l}6.3 \\
0.2\end{array}$ & $\begin{array}{l}24 \\
1.4 \\
9.2 \\
80 / 50 \\
0.7\end{array}$ & $\begin{array}{c}16 \\
0.71 \\
4.6 \\
130 / 90 \\
0.9\end{array}$ & $\begin{array}{l}5.3 \\
1.1\end{array}$ & $\begin{array}{c}4 \\
0.17 \\
0 \\
165 / 105 \\
1.6\end{array}$ & $\begin{array}{c}37 \\
1.8 \\
10.9 \\
160 / 100 \\
1.7\end{array}$ \\
\hline \multicolumn{11}{|l|}{214} \\
\hline $\begin{array}{l}\text { Aldosterone* } \\
\text { Corticosterone } \dagger \\
\text { 17-OH corticoids } \dagger \\
\text { Blood pressureł } \\
\text { Plasma flow§ }\end{array}$ & $\begin{array}{c}0 \\
0.73 \\
0.2 \\
125 / 75 \\
1.1\end{array}$ & $\begin{array}{l}1.0 \\
0.7\end{array}$ & $\begin{array}{c}7 \\
0.15 \\
1.5 \\
130 / 80 \\
0.7\end{array}$ & $\begin{array}{l}18 \\
\quad 0.37 \\
3.4 \\
70 / 30 \\
0.3\end{array}$ & $\begin{array}{l}6.0 \\
0.4\end{array}$ & $\begin{array}{c}48 \\
0.90 \\
5.7 \\
115 / 65 \\
0.6\end{array}$ & $\begin{array}{c}63 \\
0.97 \\
5.5 \\
135 / 80 \\
0.9\end{array}$ & $\begin{array}{l}1.3 \\
0.9\end{array}$ & $\begin{array}{c}30 \\
0.39 \\
2.6 \\
135 / 80 \\
1.1\end{array}$ & $\begin{array}{c}98 \\
3.0 \\
16.1 \\
135 / 80 \\
1.6\end{array}$ \\
\hline \multicolumn{11}{|l|}{222} \\
\hline $\begin{array}{l}\text { Aldosterone* } \\
\text { Corticosterone } \dagger \\
\text { 17-OH corticoids } \dagger \\
\text { Blood pressure } \\
\text { Plasma flow§ }\end{array}$ & $\begin{array}{c}11 \\
1.3 \\
7.9 \\
160 / 100 \\
0.9\end{array}$ & $\begin{array}{c}13 \\
1.6 \\
8.0 \\
1.1\end{array}$ & $\begin{array}{c}8 \\
1.3 \\
6.5 \\
150 / 100 \\
1.2\end{array}$ & $\begin{array}{l}36 \\
1.8 \\
7.6 \\
165 / 40 \\
0.4\end{array}$ & $\begin{array}{l}7.9 \\
0.4\end{array}$ & $\begin{array}{c}37 \\
2.1 \\
8.0 \\
120 / 80 \\
0.4\end{array}$ & $\begin{array}{c}24 \\
1.9 \\
7.5 \\
155 / 105 \\
0.5\end{array}$ & $\begin{array}{l}7.8 \\
0.5\end{array}$ & $\begin{array}{c}10 \\
1.4 \\
6.9 \\
150 / 105 \\
0.6\end{array}$ & $\begin{array}{c}69 \\
1.2 \\
8.5 \\
150 / 100 \\
0.7\end{array}$ \\
\hline \multicolumn{11}{|l|}{215} \\
\hline $\begin{array}{l}\text { Aldosterone* } \\
\text { Corticosterone } \dagger \\
\text { 17-OH corticoids } \dagger \\
\text { Blood pressure } \\
\text { Plasma flow§ }\end{array}$ & $\begin{array}{c}10 \\
0.78 \\
6.4 \\
125 / 73 \\
0.4\end{array}$ & $\begin{array}{l}4 \\
0.52 \\
3.4 \\
\\
0.3\end{array}$ & $\begin{array}{c}2 \| \\
0.13 \\
0.3 \\
125 / 75 \\
0.4\end{array}$ & $\begin{array}{l}25 \\
1.1 \\
4.1 \\
85 / 50 \\
0.2\end{array}$ & $\begin{array}{l}14 \\
0.61 \\
4.3 \\
0.3\end{array}$ & $\begin{array}{c}7 \\
0.77 \\
120 / 75 \\
0.5\end{array}$ & $\begin{array}{c}2 \| \\
0.49 \\
130 / 80 \\
0.3\end{array}$ & $\begin{array}{l}4 \\
1.2 \\
9.1 \\
0.6\end{array}$ & $\begin{array}{c}6 \\
1.3 \\
9.6 \\
120 / 80 \\
0.7\end{array}$ & $\begin{array}{c}33 \\
1.5 \\
7.9 \\
125 / 80 \\
0.8\end{array}$ \\
\hline
\end{tabular}

* Millimicrograms per minute.

$\dagger$ Micrograms per minute.

\$ Millimeters of mercury.

$\$$ Milliliters per minute.

$\|$ The quantity of aldosterone actually measured was very low in these specimens.

Two dogs (201 and 222), with high control secretion rates, showed little change following hemorrhage. In two dogs (222 and 215), although aldosterone secretion decreased after transfusion, that of corticosterone and 17-hydroxycorticoid remained the same or increased. In contrast to the uniformly large increment in aldosterone secretion following ACTH, two of five dogs showed little or no rise in corticosterone and 17-hydroxycorticoid secretion. Another dog not represented in the table, in which only 17-hydroxycorticoids were measured, showed a similar result-namely, no increment in glucocorticoid secretion following ACTH. In each instance the pre-ACTH levels of corticosterone and 17-hydroxycorticoids were high. A lack of response suggested that the rates of synthesis and release of glucocorticoids were already maximal.

Hypophysectomized dogs. In Table II are shown the experimental data from the hypophysectomized dogs. Gross inspection of the hypothalamus and sella turcica revealed no evidence of pituitary tissue. Serial sections for histological examination were not routinely made. However, the low levels of glucocorticoid secretion are compatible with complete hypophysectomy. Acute hemorrhage caused a prompt rise of aldosterone secretion which was evident in the first posthemorrhage period, in nine of ten hypophysectomized dogs. In six of the ten dogs, the rise 
was sustained throughout the post-hemorrhage period. Transfusion of the shed blood resulted in a decrement in aldosterone in three of these six, although Dog 15-60 had an unexplained rise in aldosterone secretion in the last post-transfusion period. As in the normal dog, ACTH produced a marked increment in aldosterone secretion. The secretory level attained following ACTH was always greater than the level following hemorrhage. The control secretory rates of 17-hydroxycorticoids were low in all dogs. In eight of nine dogs there was no significant change in 17hydroxycorticoid secretion following hemorrhage. One dog (62) showed a slight rise, but the change is probably within the errors of the chemical method and the levels were well below those of the post-hemorrhage normal dogs. Corticosterone secretion was low in the four dogs in which it was measured. Although there was a slight increment following hemorrhage, the values obtained were well below the values seen in the post-hemorrhage normal dog. Moreover, alterations in corticosterone secretion did not always parallel alterations in aldosterone secretion. Intravenous administration of ACTH resulted in a marked rise in both corticosterone and 17-hydroxycorticoid secretion in every dog to levels comparable with those in the post-ACTH period of normal

TABLE II

Effect of acute hemorrhage upon adrenocortical secretions in hypophysectomized dogs

\begin{tabular}{|c|c|c|c|c|c|c|c|c|c|c|}
\hline \multirow[b]{2}{*}{ Dog no. } & \multicolumn{3}{|c|}{ Control period } & \multicolumn{3}{|c|}{ Post-hemorrhage period } & \multicolumn{3}{|c|}{ Post-transfusion period } & \multirow{2}{*}{$\begin{array}{c}\text { Post-ACTH } \\
\text { period } \\
\mathbf{1 0}\end{array}$} \\
\hline & 1 & 2 & 3 & 4 & 5 & 6 & 7 & 8 & 9 & \\
\hline \multicolumn{11}{|l|}{46} \\
\hline $\begin{array}{l}\text { Aldosterone* } \\
17-O H \text { corticoids } \dagger \\
\text { Blood pressure } \ddagger \\
\text { Plasma flow } \$\end{array}$ & $\begin{array}{c}16 \\
0 \\
125 / 90 \\
0.6\end{array}$ & & $\begin{array}{c}21 \\
0 \\
125 / 90 \\
0.6\end{array}$ & $\begin{array}{c}31 \\
100 / 75 \\
0.6\end{array}$ & $\begin{array}{l}11 \\
1.0\end{array}$ & $\begin{array}{c}28 \\
120 / 90 \\
0.9\end{array}$ & $\begin{array}{c}29 \\
0 \\
130 / 105 \\
1.1\end{array}$ & & $\begin{array}{c}26 \\
100 / 70 \\
1.5\end{array}$ & \\
\hline \multicolumn{11}{|l|}{51} \\
\hline $\begin{array}{l}\text { Aldosterone* } \\
17-\text { OH corticoids } \dagger \\
\text { Blood pressure } \ddagger \\
\text { Plasma flow }\end{array}$ & $\begin{array}{c}11 \\
0 \\
100 / 80 \\
1.5\end{array}$ & 0 & $\begin{array}{c}15 \\
0.9 \\
120 / 70 \\
1.2\end{array}$ & $\begin{array}{l}21 \\
0.9 \\
80 / 40 \\
0.6\end{array}$ & $\begin{array}{c}18 \\
0.6 \\
1.4\end{array}$ & $\begin{array}{c}34 \\
1.0 \\
100 / 50 \\
1.8\end{array}$ & $\begin{array}{c}5 \| \\
130 / 75 \\
2.0\end{array}$ & $\begin{array}{l}5 \| \\
0 \\
1.9\end{array}$ & $\begin{array}{c}9 \\
0 \\
125 / 70 \\
2.0\end{array}$ & \\
\hline \multicolumn{11}{|l|}{53} \\
\hline $\begin{array}{l}\text { Aldosterone* } \\
17-0 H \text { corticoids } \dagger \\
\text { Blood pressure } \ddagger \\
\text { Plasma flow§ }\end{array}$ & $\begin{array}{c}0 \\
0 \\
145 / 100 \\
1.8\end{array}$ & $\begin{array}{l}0 \\
2.1\end{array}$ & $\begin{array}{c}0 \\
0 \\
145 / 100 \\
2.3\end{array}$ & $\begin{array}{c}0 \\
110 / 75 \\
3.0\end{array}$ & 3.1 & $\begin{array}{c}17 \\
120 / 75 \\
2.3\end{array}$ & $\begin{array}{c}17 \\
125 / 55 \\
3.2\end{array}$ & 2.0 & $\begin{array}{c}23 \\
130 / 80 \\
1.9\end{array}$ & $\begin{array}{c}73 \\
135 / 85 \\
2.7\end{array}$ \\
\hline \multicolumn{11}{|l|}{62} \\
\hline $\begin{array}{l}\text { Aldosterone* } \\
17-0 H \text { corticoids } \dagger \\
\text { Plasma flow }\end{array}$ & $\begin{array}{l}6 \\
0.1 \\
1.2\end{array}$ & $\begin{array}{l}0.1 \\
1.4\end{array}$ & $\begin{array}{l}0 \\
0 \\
1.5\end{array}$ & $\begin{array}{r}22 \\
1.3 \\
1.3\end{array}$ & $\begin{array}{l}1.3 \\
1.5\end{array}$ & $\begin{array}{l}8 \\
1.1 \\
1.4\end{array}$ & $\begin{array}{l}9 \\
0 \\
1.4\end{array}$ & $\begin{array}{l}0.1 \\
1.3\end{array}$ & $\begin{array}{r}23 \\
0.9 \\
1.2\end{array}$ & $\begin{array}{r}97 \\
3.6 \\
1.4\end{array}$ \\
\hline \multicolumn{11}{|l|}{55} \\
\hline $\begin{array}{l}\text { Aldosterone* } \\
17-O H \text { corticoids } \dagger \\
\text { Blood pressure } \ddagger \\
\text { Plasma flow } \$\end{array}$ & $\begin{array}{c}0 \\
0 \\
125 / 75 \\
1.7\end{array}$ & $\begin{array}{l}0.7 \\
1.1\end{array}$ & $\begin{array}{c}0 \\
0 \\
125 / 75 \\
1.3\end{array}$ & $\begin{array}{c}5 \\
59 / 9 \\
0.4\end{array}$ & 0.9 & $\begin{array}{c}0 \\
80 / 30 \\
1.1\end{array}$ & $\begin{array}{c}0 \\
115 / 60 \\
1.6\end{array}$ & 1.2 & $\begin{array}{c}0 \\
120 / 50 \\
1.1\end{array}$ & $\begin{array}{c}29 \\
120 / 50 \\
1.1\end{array}$ \\
\hline \multicolumn{11}{|l|}{197} \\
\hline $\begin{array}{l}\text { Aldosterone* } \\
17-O H \text { corticoids } \dagger \\
\text { Blood pressure } \ddagger \\
\text { Plasma flow§ }\end{array}$ & $\begin{array}{c}8 \\
0.7 \\
110 / 70 \\
1.1\end{array}$ & $\begin{array}{l}1.2 \\
1.4\end{array}$ & $\begin{array}{l}8 \\
0.7 \\
85 / 50 \\
1.7\end{array}$ & $\begin{array}{l}26 \\
0.6 \\
60 / 40 \\
0.8\end{array}$ & & $\begin{array}{l}31 \\
1.8 \\
70 / 50 \\
1.3\end{array}$ & $\begin{array}{c}21 \\
1.7 \\
120 / 80 \\
1.4\end{array}$ & $\begin{array}{l}0.7 \\
1.7\end{array}$ & $\begin{array}{c}20 \\
1.2 \\
90 / 70 \\
2.1\end{array}$ & $\begin{array}{c}51 \\
6.5 \\
100 / 75 \\
2.3\end{array}$ \\
\hline
\end{tabular}

* Millimicrograms per minute.

† Micrograms per minute.

$\ddagger$ Millimeters of mercury.

$\$$ Milliliters per minute.

II The quantity of aldosterone actually measured was very low in these specimens. 
TABLE II-(Continued)

\begin{tabular}{|c|c|c|c|c|c|c|c|c|c|c|}
\hline \multirow[b]{2}{*}{ Dog no. } & \multicolumn{3}{|c|}{ Control period } & \multicolumn{3}{|c|}{ Post-hemorrhage period } & \multicolumn{3}{|c|}{ Post-transfusion period } & \multirow{2}{*}{$\begin{array}{c}\text { Post-ACTH } \\
\text { period } \\
10\end{array}$} \\
\hline & 1 & 2 & 3 & 4 & 5 & 6 & 7 & 8 & 9 & \\
\hline \multicolumn{11}{|l|}{204} \\
\hline $\begin{array}{l}\text { Aldosterone* } \\
\text { Corticosterone } \dagger \\
\text { 17-OH corticoids } \dagger \\
\text { Blood pressure } \\
\text { Plasma flow§ }\end{array}$ & $\begin{array}{l}8 \\
0.26 \\
0 \\
135 / 85 \\
\quad 1.8\end{array}$ & $\begin{array}{l}0.7 \\
1.9\end{array}$ & $\begin{array}{c}1 \| \\
0.25 \\
0 \\
135 / 80 \\
1.8\end{array}$ & $\begin{array}{l}9 \\
0.41 \\
0 \\
85 / 50 \\
1.0\end{array}$ & $\begin{array}{l}0 \\
0.8\end{array}$ & $\begin{array}{c}14 \\
0.45 \\
0 \\
125 / 90 \\
1.2\end{array}$ & $\begin{array}{c}8 \\
0.21 \\
1.0 \\
125 / 100 \\
1.1\end{array}$ & $\begin{array}{l}0 \\
0.9\end{array}$ & $\begin{array}{c}17 \\
0.66 \\
0 \\
130 / 100 \\
1.1\end{array}$ & $\begin{array}{c}93 \\
3.4 \\
9.9 \\
125 / 100 \\
1.4\end{array}$ \\
\hline \multicolumn{11}{|l|}{301} \\
\hline $\begin{array}{l}\text { Aldosterone* } \\
\text { Corticosterone } \dagger \\
17-0 H \text { corticoids } \dagger \\
\text { Blood pressure } \\
\text { Plasma flow§ }\end{array}$ & $\begin{array}{c}20 \\
0.036 \\
0.2 \\
150 / 100 \\
1.9\end{array}$ & $\begin{array}{l}12 \\
0.047 \\
0 \\
1.6\end{array}$ & $\begin{array}{c}13 \\
0.035 \\
0 \\
140 / 85 \\
1.4\end{array}$ & $\begin{array}{l}23 \\
0.065 \\
0.1 \\
60 / 30 \\
0.9\end{array}$ & $\begin{array}{l}6 \\
0.050 \\
0.9\end{array}$ & $\begin{array}{c}7 \\
0.071 \\
0 \\
100 / 60 \\
1.1\end{array}$ & $\begin{array}{c}4 \\
0.14 \\
125 / 75 \\
1.2\end{array}$ & $\begin{array}{l}3 \\
0.016 \\
0.2 \\
1.1\end{array}$ & $\begin{array}{c}15 \\
0.028 \\
0 \\
125 / 80 \\
1.0\end{array}$ & $\begin{array}{c}53 \\
1.4 \\
5.8 \\
125 / 80 \\
1.2\end{array}$ \\
\hline \multicolumn{11}{|l|}{$3-60$} \\
\hline $\begin{array}{l}\text { Aldosterone* } \\
\text { Corticosterone } \dagger \\
17-\text {-H corticoids } \dagger \\
\text { Blood pressure } \\
\text { Plasma flow } \$\end{array}$ & $\begin{array}{c}37 \\
0.057 \\
0 \\
175 / 105 \\
1.0\end{array}$ & $\begin{array}{l}37 \\
0.058 \\
0 \\
1.1\end{array}$ & $\begin{array}{c}32 \\
0.048 \\
0 \\
160 / 100 \\
0.9\end{array}$ & $\begin{array}{l}43 \\
0.12 \\
0 \\
65 / 30 \\
0.7\end{array}$ & & $\begin{array}{c}37 \\
0.23 \\
0.4 \\
100 / 50 \\
0.4\end{array}$ & $\begin{array}{c}41 \\
0.096 \\
0.2 \\
160 / 95 \\
0.8\end{array}$ & $\begin{array}{l}38 \\
0.16 \\
0.2 \\
\\
1.0\end{array}$ & $\begin{array}{c}30 \\
0.13 \\
0.2 \\
120 / 70 \\
1.0\end{array}$ & $\begin{array}{c}67 \\
2.1 \\
7.0 \\
125 / 75 \\
1.0\end{array}$ \\
\hline \multicolumn{11}{|l|}{$15-60$} \\
\hline $\begin{array}{l}\text { Aldosterone* } \\
\text { Corticosterone } \dagger \\
17-0 H \text { corticoids } † \\
\text { Blood pressure } \\
\text { Plasma flow§ }\end{array}$ & $\begin{array}{c}0 \\
0.026 \\
0 \\
150 / 105 \\
1.4\end{array}$ & $\begin{array}{l}0.025 \\
0 \\
1.8\end{array}$ & $\begin{array}{c}2 \| \\
0.034 \\
0 \\
150 / 105 \\
1.7\end{array}$ & $\begin{array}{c}8 \\
0.036 \\
0 \\
140 / 105 \\
1.5\end{array}$ & $\begin{array}{l}8.0 \\
0.10 \\
0 \\
2.1\end{array}$ & $\begin{array}{c}10 \\
0.30 \\
0 \\
150 / 105 \\
1.2\end{array}$ & $\begin{array}{c}3.0 \\
0.02 \\
0 \\
175 / 110 \\
0.8\end{array}$ & $\begin{array}{l}4 \\
0.015 \\
0 \\
\\
0.4\end{array}$ & $\begin{array}{c}23 \\
0.071 \\
0 \\
170 / 120 \\
1.6\end{array}$ & $\begin{array}{c}16 \\
2.3 \\
5.4 \\
170 / 120 \\
2.6\end{array}$ \\
\hline
\end{tabular}

dogs, indicating the presence of a responsive adrenal.

In Figure 1 is represented a summary of the aldosterone results. All values are the average of

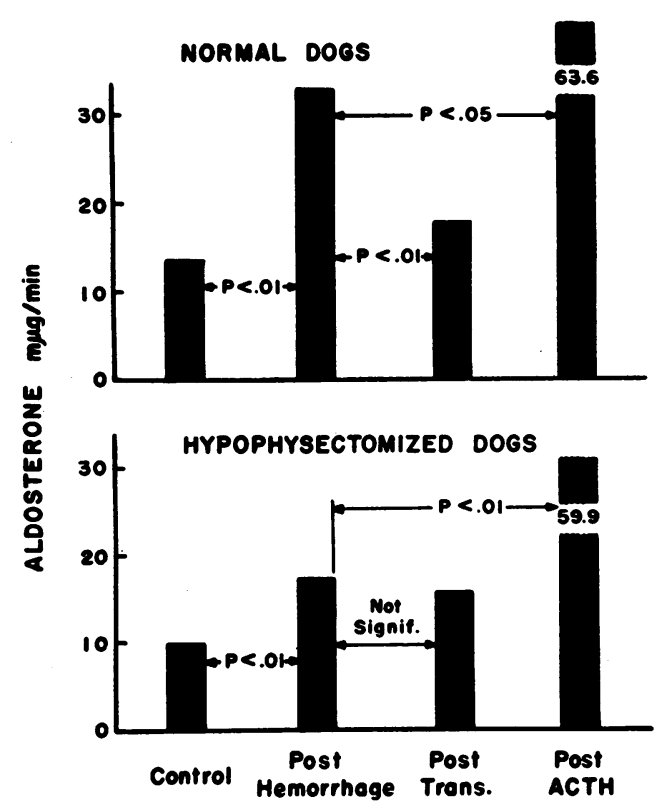

Fig. 1. Summary of ALDOSTERONe RESUlts IN NORMAL AND IN HYPOPHYSECTOMIZED DOGS. two or three samples in each period for each dog. Only eight of the hypophysectomized dogs received ACTH. The $\mathrm{p}$ values were obtained by the paired $t$ test. The increment in aldosterone secretion following hemorrhage in the normal and hypophysectomized dogs is significant- $\mathrm{p}<0.1$. Following transfusion of shed blood there is a decrease in the secretory rates of normal dogs but no significant change in the hypophysectomized dogs. The highest level of secretion occurs postACTH with approximately the same levels in both groups. In the post-hemorrhage period, the mean secretory level of the normal dogs is significantly greater than that of the hypophysectomized dogs $-p<0.05$. The secretory levels, however, do not differ significantly in the control, post-transfusion or post-ACTH periods between the two groups of dogs.

\section{DISCUSSION}

Farrell, Rosnagle and Rauschkolb (1) were the first to show that hemorrhage stimulates aldosterone secretion in dogs. Although aldosterone was affected to a greater extent than cortisol, in several dogs the increment in cortisol secretion was appreciable. Fine, Meiselas 
and Auerbach (2) noted an increment in the urinary excretion of aldosterone in normal humans following acute hemorrhage without any appreciable change in 17-hydroxycorticoid excretion. This increment lasted 1 to 2 days and could not be prevented by expansion of intravascular volume with the administration of 25 per cent albumin immediately after the hemorrhage. Bartter, Biglieri, Pronove and Delea (3) have also demonstrated that phlebotomy in sodium-depleted humans resulted in an increment in aldosterone excretion that was not prevented by administration of a volume of isotonic saline equivalent to the saline removed by phlebotomy. Spontaneous hemodilution and reinfusion of red blood cells did result in a decrement in aldosterone output. From their studies in the dog, Gann, Mills and Bartter (13) have concluded that the increment following hemorrhage is dependent upon an intact nerve to the thyrocarotid arterial junction and that the decrease in carotid arterial pressure specifically stimulates the release of aldosterone, presumably through release of a humoral factor. However, glucocorticoid secretion was never measured. Whether the nerve influences glucocorticoid secretion has not been determined. Experiments by Walker, Shoemaker, Kaalstad and Moore (14) have shown that acute hemorrhage may stimulate 17-hydroxycorticoid secretion.

The present study indicates that two mechanisms play a role in the increment in adrenocortical secretions following hemorrhage. The pituitary via ACTH release stimulates both glucocorticoid and aldosterone secretion. The marked increment in 17-hydroxycorticoid and corticosterone secretion following hemorrhage in the three normal dogs with low control secretory levels indicates an ACTH effect. Moreover, the demonstration that exogenous ACTH stimulated both glucocorticoid and aldosterone secretion in the normal and hypophysectomized dogs, and the greater increment in aldosterone secretion in the normal dogs following hemorrhage, are evidence that endogenous ACTH also can stimulate aldosterone output. The increment in glucocorticoid secretion following hemorrhage and the decrement following transfusion in normal dogs suggest that the release of $\mathrm{ACTH}$ is responsive to changes in intravascular volume, possibly mediated through the baroreceptor nerves.
A mechanism independent of the pituitary must also be involved, since aldosterone secretion rises following hemorrhage in the hypophysectomized dogs. A great deal of evidence indicates that this mechanism is humoral (15-18). The response within 15 minutes suggests that some component of intravascular volume, pressure or flow is the stimulus. The present experiments do not distinguish between a direct effect on the adrenal or stimulation by a humoral factor from a remote. site. The studies of Farrell (15) indicate that such a site is in the head. However, Davis, Carpenter, Ayers and Bahn (19), who also found a rise in aldosterone secretion following hemorrhage in hypophysectomized dogs, present the rise in aldosterone secretion following hemorrhage in decapitated dogs as evidence for a more caudal origin of the proposed hormone.

The studies with ACTH in the normal dogs point out the hazards of comparing the relative change in glucocorticoid secretion with the relative change in aldosterone secretion, as an index of either ACTH or a specific aldosterone-stimulating factor. The metabolic state of the adrenal gland may alter the pattern of response to ACTH. Davis and colleagues (8) reported that infusion of ACTH into hypophysectomized, sodium-depleted dogs stimulated mainly aldosterone secretion. From the present study, it appears that in the acute experiment when glucocorticoids are being maximally produced, addition of ACTH stimulates mainly aldosterone secretion, as if it were a specific aldosterone-stimulating hormone. In Figure 2 is illustrated a possible explanation of this effect. Koritz and Peron (20) have proposed that the action of ACTH is twofold: to increase available TPNH by augmenting adrenal phosphorylase and to increase available steroid precursors. If at the maximal secretory rate of 17-hydroxycorticoids and corticosterone, the ratelimiting factor is available TPNH, then the steroid precursors could be synthesized to aldosterone through a less TPNH-dependent pathway than through corticosterone. Several workers (21, 22) have actually suggested another pathway directly from progesterone, although its dependence upon TPNH or other factors is not known.

When glucocorticoid synthesis is not at a maximal rate, ACTH stimulates both glucocorticoid and aldosterone. This is particularly evident in 


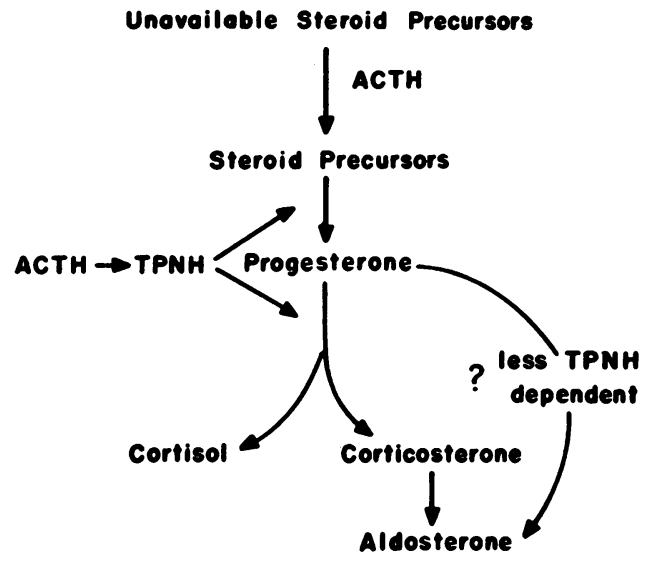

Fig. 2. Schema of ACTH stimulation of aldoSTERONE SECRETION.

the hypophysectomized dogs, in which ACTH always caused a marked increment in corticosterone and 17-hydroxycorticoid secretion. Unpublished observations by the authors, with successively increasing doses of ACTH in hypophysectomized or submaximally secreting dogs, show that the smallest dose affects glucocorticoid secretion first, while larger doses stimulate both glucocorticoid and aldosterone secretion.

These results cast some doubt on the validity of acute experiments performed in animals with intact pituitaries, since the adrenals of these animals are often secreting maximally. On the other hand, it should be kept in mind that the adrenal of the hypophysectomized dog may not respond as well to stimuli other than $\mathrm{ACTH}$ that increase aldosterone secretion, since ACTH is necessary to maintain steroidogenesis at a high level. This dependence appears to be clearly demonstrated in chronically hypophysectomized dogs, which do not respond to thoracic inferior vena cava constriction (8) as do normal dogs, and in patients with long-standing hypopituitarism who show a poor response to salt deprivation (23). However, whether this holds true to the same extent for the acutely hypophysectomized dog has not been clearly determined. Perhaps the failure to maintain the increased secretory level in the four hypophysectomized dogs is due to the absence of ACTH, although Farrell and associates (1) also noted that the secretory levels decreased despite continued blood loss in normal dogs. The present experiments, however, indicate that acute hem- orrhage can stimulate the secretion of aldosterone independently of ACTH.

\section{SUMMARY}

The effect of an acute hemorrhage upon adrenocortical secretions has been studied in the normal and in the acutely hypophysectomized dog. Hemorrhage stimulated adrenocortical secretions by two mechanisms. In the normal dog, acute hemorrhage caused release of ACTH which stimulated both glucocorticoid and aldosterone secretion. However, if glucocorticoid secretion was maximal, only aldosterone secretion was stimulated, even by exogenous ACTH. Experiments in the hypophysectomized dog demonstrated that a mechanism independent of the pituitary stimulated primarily aldosterone secretion.

\section{ACKNOWLEDGMENT}

The authors wish to thank Dr. Ralph E. Peterson for his advice and help in applying the double isotope derivative method in their laboratory, and to Mrs. Vina Cera, Mr. Walter Herniak and Mr. Roy Shackleford for their assistance in this work.

\section{REFERENCES}

1. Farrell, G. L., Rosnagle, R. S., and Rauschkolb, E. W. Increased aldosterone secretion in response to blood loss. Circulat. Res. 1956, 4, 606.

2. Fine, D., Meiselas, L. E., and Auerbach, T. The effect of acute hypovolemia on the release of "aldosterone" and on the renal excretion of sodium. J. clin. Invest. 1958, 37, 232.

3. Bartter, F. C., Biglieri, E. G., Pronove, P., and Delea, C. S. Effect of changes in intravascular volume on aldosterone secretion in man in An Internat. Symp. on Aldosterone, A. F. Muller and C. M. O'Connor, Eds. London, J. and A. Churchill, 1958, p. 100.

4. Singer, B., and Stack-Dunne, M. P. The secretion of aldosterone and corticosterone by the rat adrenal. J. Endocr. 1955, 12, 130.

5. Farrell, G. L., Fleming, R. B., Rauschkolb, E. W., Yatsu, F. M., McCally, M., and Anderson, C. H. Steroidogenic properties of purified corticotropins. Endocrinology 1958, 62, 506.

6. Ganong, W. F., Lieberman, A. H., Daily, W. J. R., Yuen, V. S., Mulrow, P. J., Luetscher, J. A., Jr., and Bailey, R. E. Aldosterone secretion in dogs with hypothalamic lesions. Endocrinology 1959, 65, 18.

7. Davis, J. O., Bahn, R. C., Yankopoulos, N. A., Kliman, B., and Peterson, R. E. Acute effects of hypophysectomy and diencephalic lesions on al- 
dosterone secretion. Amer. J. Physiol. 1959, 197, 380.

8. Davis, J. O., Yankopoulos, N. A., Lieberman, F., Holman, J., and Bahn, R. C. The role of the anterior pituitary in the control of aldosterone secretion in experimental secondary hyperaldosteronism. J. clin. Invest. 1960, 39, 765.

9. Hume, D. M., and Nelson, D. H. Adrenal cortical function in surgical shock. Surg. Forum 1954, 5, 568.

10. McLean, A. J. Transbuccal approach to the encephalon in experimental operations upon carnivoral pituitary, pons, and ventral medulla. Ann. Surg. 1928, 88, 985.

11. Kliman, B., and Peterson, R. E. Double isotope derivative assay of aldosterone in biological extracts. J. biol. Chem. 1960, 235, 1639.

12. Silber, R. H., and Porter, C. C. The determination of 17,21-dihydroxy-20-ketosteroids in urine and plasma. J. biol. Chem. 1954, 210, 923.

13. Gann, D. S., Mills, I. H., and Bartter, F. C. The hemodynamic parameter mediating increase in aldosterone secretion (abstract). Program, Fortyfirst Endocrine Society Meeting, June, 1959.

14. Walker, W. F., Shoemaker, W. C., Kaalstad, A. J., and Moore, F. D. Influence of blood volume restoration and tissue trauma on corticosteroid secretion in dogs. Amer. J. Physiol. 1959, 197, 781.

15. Farrell, G. Glomerulotropic activity of an acetone extract of pineal tissue. Endocrinology 1959, 65, 239.
16. Yankopoulos, N. A., Davis, J. O., Kliman, B., and Peterson, R. E. Evidence that a humoral agent stimulates the adrenal cortex to secrete aldosterone in experimental secondary hyperaldosteronism. J. clin. Invest. 1959, 38, 1278.

17. Orti, E., Ralli, E. P., Laken, B., and Dumm, M. E. Presence of an aldosterone stimulating substance in the urine of rats deprived of salt. Amer. J. Physiol. 1957, 191, 323.

18. Mulrow, P. J., Shmagranoff, G. L., Lieberman, A. H., Slade, C. I., and Luetscher, J. A., Jr. Stimulation of rat adrenocortical secretion by a factor present in human urine. Endocrinology 1959, 64, 631.

19. Davis, J. O., Carpenter, C., Ayers, C., and Bahn, R. C. Increased aldosterone secretion following decapitation and subsequent bleeding of hypophysectomized dogs (abstract). Program, Forty-second Endocrine Society Meeting, June 1960, p. 14.

20. Koritz, S. B., and Peron, F. G. - Studies on the mode of action of the adrenocorticotropic hormone. J. biol. Chem. 1958, 230, 343.

21. Rosemberg, E., Rosenfeld, G., Ungar, R., and Dorfman, R. S. Conversion of steroids to aldosteronelike material. Endocrinology 1956, 58, 708.

22. Travis, R. H., and Farrell, G. L. In vitro biosynthesis of isotopic aldosterone: Comparison of precursors. Endocrinology 1958, 63, 882.

23. Lieberman, A. H., and Luetscher, J. A. Effects of abnormalities of pituitary, adrenal or thyroid function on excretion of aldosterone and the response to corticotropin or sodium deprivation. J. clin. Endocr. 1960, 20, 1004. 